\title{
Wage Differentials of Intermodal Transportation Carriers and Ports: Deregulation Versus Regulation
}

\author{
WAYNE K. TALLEY* \\ The Maritime Institute, Department of Economics, Old Dominion University Norfolk
}

\begin{abstract}
This paper investigates the wage differentials of intermodal transportation carriers and ports under carrier economic regulation and deregulation. The estimation results suggest that the union wages of truck drivers, rail engineers and port dockworkers were comparable in the regulation period; in the deregulation period the union wages of truck drivers and rail engineers declined relative to those of dockworkers. The wage differential estimates indicate negative union hourly wage gaps for truck drivers and rail engineers of $22.7 \%$ and $6.9 \%$, respectively, versus dockworkers. These results reflect the increase (decrease) in the relative bargaining power of dockworkers (truck drivers and rail engineers) in the deregulation period.
\end{abstract}

\section{Introduction}

While shippers and passengers have generally benefitted from economic deregulation of transportation carrier industries, paying lower real rates and fares, the impact on carrier labor earnings has generally been negative. In the U.S., for example, the real weekly wages of union railroad engineers have declined $11.7 \%$ (Talley and Schwarz-Miller, 1998) and the real hourly wages of union and non-union for-hire truck carrier drivers have declined $23 \%$ and $10 \%$ (Hirsch and Macpherson, 1998) under railroad and trucking deregulation. Evidence also suggests that the relative wages of transportation carrier industries tend to widen under deregulation. Talley (2001) found that in the U.S. the union wages of railroad occupations have increased relative to those of truck drivers and the union wages of truck drivers have increased relative to those of motor bus drivers.

The economic deregulation of transportation carriers may affect not only the wages of carrier workers but also the wages of workers of inter-related industries, that is, industries that provide supplies and services to the carriers. Unlike that for carrier workers, there has been little investigation of the impact of transportation carrier deregulation on the labor earnings of interrelated industries. One exception is a study of the impact of shipping deregulation on port labor

\footnotetext{
* Department of Economics, Old Dominion University, Norfolk, Virginia 23529. E-mail: wktalley@,odu.edu
} 
earnings. Talley (2002) found that the real hourly and weekly wages of U.S. union dockworkers increased $14.3 \%$ and $15.3 \%$, respectively, in the shipping deregulation period. These results are in contrast to those found in the transportation carrier literature, where carrier wages declined in the deregulation period.

To the knowledge of the author, an investigation of the wage differentials of carrier workers and the workers of inter-related industries following carrier deregulation has not appeared in the literature. Specifically, have these wage differentials changed from those of the regulation period? If so, have these differentials widened (narrowed) under deregulation, thereby increasing (decreasing) the gap in the labor earnings among transportation carrier and inter-related industries?

The purpose of this paper is to investigate occupational wage differentials among transportation carrier and inter-related industries under carrier economic regulation and deregulation. Two transportation carrier (railroad and truck) industries and one inter-related (the port) industry are utilized in the investigation. The occupations of the railroad, truck and port industries include: railroad engineers, truck drivers and dockworkers, respectively. Wage differentials for U.S. truck drivers versus dockworkers and rail engineers versus dockworkers are estimated for carrier regulation and deregulation periods. As competition among intermodal carriers and among ports intensifies, wage differentials among these industries, as found in this paper, are expected to play a more important role in industry wage negotiations.

The remainder of the paper is structured as follows. Section 2 discusses railroad, truck and shipping carrier industries under U.S. economic regulation and deregulation, followed by a discussion of port dockworkers in Section 3. The data and wage model are presented in Section 4 , followed by a presentation of the estimation results in Section 5. Conclusions are set forth in Section 6.

\section{Transportation carrier industries under regulation and deregulation}

\subsection{Railroad carrier industry}

Federal economic regulation of the U.S. railroad industry began with passage of the Interstate Commerce Act in 1887, establishing the Interstate Commerce Commission (ICC) as the regulatory authority over industry rates, entry, services and finances. The Act protected railroads from intramodal, but not from intermodal competition. By the 1970s, the poor financial status of railroads prompted Congress to deregulate the industry, passing the Railroad Revitalization and Regulatory Reform (the 4-R) Act of 1976 and the Staggers Rail Act of 1980. The former introduced limited industry rate-making freedom and made it easier for railroads to abandon unprofitable lines. The Staggers Act allows service contracts and therefore contract rates; establishes rate floors and ceilings; and expedites the ICC (now the Surface Transportation 
Board) timetable on merger applications. ${ }^{1}$ In the deregulation period, railroad rates of return have risen significantly ${ }^{2}$ - attributable in part to cost savings and to improvements in service ${ }^{3}$ and managerial effectiveness. ${ }^{4}$

While shareholders (from higher returns) and shippers (from lower real rates ${ }^{5}$ and improved service) have benefited from railroad deregulation, the impact on labor has been negative. ${ }^{6}$ The number of railroad jobs has declined significantly in an effort by the industry to reduce labor costs. In 1975, the industry had 548,000 (488,000 Class I) employees; by 1985 and 1995 the number had declined to 372,000 (302,000 Class I) and 265,000 (188,000 Class I) employees; and by 2000 the number had declined to 246,000 (168,000 Class I) employees (Association of American Railroads, 2002). The adoption of industry labor-saving technologies facilitated this decline: Electronic-based communications and information systems have made it possible to automate almost every phase of traffic control, signaling, car management, train dispatching and make-up, and train movement as well as such administrative functions as waybill transmission and the handling of freight and loss-and-damage claims. ${ }^{7}$

\footnotetext{
${ }^{1}$ For further discussion, see Braeutigam (1993). Since neither the 4-R Act nor the Staggers Act completely deregulated the rail industry, some authors prefer to use the phrase "regulatory reform" rather than the term "deregulation". We choose the latter for this paper.

${ }^{2}$ In 1980, railroads' rate of return on net investment was $4.22 \%$, rising to levels of $4.58 \%$ and $7.04 \%$ in 1985 and 1995, and falling slightly to 6.93\% in 1999 (Association of American Railroads, 2002). McFarland (1987, 1989) has investigated whether this improvement resulted in excess profits for the industry. Based on an analysis of 1980-84 data in his 1987 paper and an analysis of 1985-86 data in his 1989 paper, McFarland found no such evidence. The ICC also tests annually for excessive railroad profits utilizing the revenue adequacy test: A railroad is judged to be revenue-adequate if its rate of return on investment exceeds the market cost of capital; if so, it becomes subject to stricter rate regulation than a revenue-inadequate railroad. For the 1982-87 period, the ICC never found a railroad to be revenue-adequate; subsequently, however, several railroads have been so classified.

${ }^{3}$ The Staggers Act permitted railroads to enter into separate service contracts with shippers. In the first five years of the Staggers period, 41,021 contracts were filed with the ICC, resulting in railroads becoming more time-sensitive.

For example, automakers are using rail service to deliver parts to the factory door in as little as two hours before the part is needed on the assembly line.

${ }^{4}$ Friedlaender et al. (1992) hypothesize that the railroad industry has steadily evolved under deregulation from a regime in which railroad managers balanced their own interests against the interest of shareholders to a regime in which rail managers are more directly subject to shareholder influence.

${ }^{5}$ Wilson (1994) concludes that real rail rates have fallen since passage of the Staggers Act. Initially, deregulation increased rates for some commodities, decreased rates on others, and had no effect on still others, but by 1988 deregulation had lowered rates significantly for almost all commodities. Other deregulation studies focusing on rail rates of specific commodities include studies by MacDonald (1989) and Burton (1993). For a discussion of the impact of deregulation on aggregate rail rates, see Boyer (1987), Barnekov and Kliet (1990), and McFarland (1989).

${ }^{6}$ Prior to deregulation the heavily-unionized rail industry operated in a high labor-cost environment, reflecting use of an excessive amount of labor, costly work and pay rules, and high wage rates. Under regulation, increases in labor costs were typically passed on to customers through higher rail rates. Adhering to this strategy, however, has become increasingly difficult in the deregulation period, as railroads face competition from a deregulated trucking industry as well as from one another.

${ }^{7}$ The decline also reflects job losses attributed to mergers, line abandonments, the sale of lines to shortline railroads, and modifications in restrictive work rules. Over 100 new shortline railroads have entered the industry since 1980 and in many cases have taken over branch lines which otherwise would have been abandoned. Further, the evolution toward fewer, but longer and heavier, freight trains as well as toward longer runs without crew
} 
While the number of railroad jobs has declined in the deregulation period, the productivity of the remaining workers has increased. The revenue ton-miles of Class I railroads per employee was 2.1 in 1980, increasing to 2.9, 7.0 and 8.8 in 1985, 1995 and 2000, respectively (Association of American Railroads, 2002). The increase in labor productivity has not only been enhanced by technological improvements in electronics, communications and information technology, but also from technological improvements in railroad capital, that is, in locomotives, tracks and cars (Schwarz-Miller and Talley, 2002). As for railroad jobs, the bargaining power of railroad workers has also declined in the deregulation period. The 1985-88 industry-wide union contract, in particular, resulted in a shift in the balance of power from rail labor to management. Before 1985 pay increases were granted at least annually and supplemented by regular cost-of-living adjustments (COLA) payments. In the 1985-88 contract agreement, pay increases were smaller and certain types of pay were frozen or modified; the COLA provision was less liberal; and a two-tier pay system was introduced. Between December 1987 and July 1991 no changes were made in base pay; the 1991-95 agreement called for moderate nominal increases in base pay, but no COLA until January 1995.

\subsection{Truck carrier industry}

The U.S. Motor Carrier Act of 1935 placed truck carriers, engaged in intercity, interstate for-hire truck services, under the regulatory authority of the ICC. By the early 1970s critics of ICC truck regulation noted waste and inefficiency, absence of competition and high rates in the industry. ${ }^{8}$ By the late 1970s ICC administrative deregulation of the for-hire truck carrier industry was underway. In July 1980 Congress passed the Motor Carrier Act of 1980 (1980 MCA) which substantially reduced ICC regulation of the industry, accelerating ICC administrative deregulation. Entry restrictions were eased; contract carriers were permitted to hold common carrier certificates; and the discounting of rates was permitted within a zone of rate freedom.

Following passage of the 1980 MCA the number of trucking firms increased dramatically, more than doubling by 1987. Many of the new entrants were truckload (TL) carriers. Whereas TL carriers are mostly non-union, less-than-truckload (LTL) carriers have remained highly unionized, but have declined in number. Thus, the concentration of TL (LTL) carriers has declined (increased). ${ }^{9}$

changes have reduced the need for train and engine employees. In 1980 the average freight train carried 2,222 tons of freight; by 1990 and 1999 the tonnage was 2,755 and 2,947 (the highest ever recorded) tons (Association of American Railroads, 2002). For a discussion of declining rail employment levels and the adoption of labor-saving technologies, see Rich (1986), Gil (1986), and Crum (1989). A discussion of the impact of post-1980 transportation policy changes, for example passage of the Motor Carrier Act of 1980, on rail employment is found in Babcock and German (1991).

${ }^{8}$ Regulated truck carriers were restricted to hauling only those commodities for which they had the authority to do so which often resulted in their trucks running empty on return trips. The routes of regular route carriers were often not direct but circuitous, resulting in wasted fuel and operating inefficiencies. Although there were approximately 18,000 truck carriers under ICC regulation, there were generally only a few carriers serving particular city pairs. Rates were based on value of service and not necessarily on the costs incurred in providing the service.

${ }^{9}$ Nebesky, McMullen and Lee (1995) conclude that, given the prevalence of competitive pricing behavior, increased industry concentration in the LTL market in the deregulation period does not imply anti-competitive 
Regulation provided the opportunity for union truck drivers to realize rents (Rose, 1987), for example, from ICC entry and rate competition restrictions and through national bargaining (culminating in National Master Freight Agreements, NMFAs). Under deregulation, union jobs and the membership of the Teamster union (the primary union representing truck carriers) declined, while the size of the driver work force increased from 1.1 million in 1978 to 1.9 million by 1996 (Peoples, 1998). Further, carrier participation in NMFAs declined. ${ }^{10}$

As for railroad workers, the productivity of truck drivers has also increased in the deregulation period. Driver productivity has been enhanced by improvements in communications technologies - satellite systems, beepers, cell phones and two-way radios - that locate trucks in real time and permit communication between the truck carrier and the driver without requiring the driver to stop (Monaco and Belman, forthcoming). Also, these technologies allow truck carriers to monitor drivers to improve their productivity by reducing unauthorized breaks. Driver productivity has also been enhanced from improvements in logistics software that allow dispatchers to better coordinate trips and higher load factors and from changes in safety regulations that allow longer and heavier trucks on the highway.

Also as for railroad workers, the bargaining power of truck drivers has declined in the deregulation period, but much earlier than for the former. The 1982 NMFA contract froze wages for three years and established new work rules to make NMFA carriers more competitive with non-union carriers. The 1985 NMFA included a two-tier wage structure, where new hires would start at $70 \%$ of scale and reach full scale in three years. The 1988 NMFA institutionalized Employee Stock Ownership Plans (ESOPs); when substituted for wage increases, these profit sharing plans resulted in wage cuts for employees of financially troubled carriers. The 1994 NMFA (expiring in 1998), preceded by a 24 day strike, the longest strike in the history of NMFAs, provided for modest wage increases; new hires would start at $75 \%$ of scale and reach full scale in two years (Belzer, 1995). ${ }^{11}$

\subsection{Shipping carrier industry}

The U.S. Shipping Act of 1916 created the U. S. Shipping Board (renamed the Federal Maritime Commission in 1961) to have "jurisdiction over common carriers by water operating in interstate or foreign commerce on the high seas and upon the Great Lakes" (Locklin, 1972, p. 746), but not jurisdiction over inland waterways. ${ }^{12}$ The Act legalized shipping liner conference ${ }^{13}$ agreements

performance. "The substantial reduction in the number of LTL carriers following regulatory reform in 1980 may reflect superior efficiency of surviving firms," Nebesky, McMullen and Lee (1995, p. 571).

${ }^{10}$ In 1963 general freight truck carriers created the Trucking Employers Incorporated (TEI) to bargain with the Teamsters in negotiating the first NMFA. At its height TEI represented between 800 and 1,000 carriers; by the time of the 1994 NMFA negotiations, it represented only 23 carriers.

${ }^{11}$ Unlike the 1994 NMFA, the 1998 NMFA between the Teamsters union and management negotiators for LTL carriers was reached several weeks before the expiration of the current NMFA. The 1998 NMFA provides for an immediate $\$ 750$ signing bonus for LTL Teamster workers, no wage increases in the first year, but wage increases of 35 cents per hour in each of the final four years of the contract, topping out at \$19.86 an hour in 2003.

12 The Transportation Act of 1940 placed inland, other than Great Lakes, waterway transportation under the jurisdiction of the ICC. 
by granting them immunity from anti-trust legislation. The Shipping Act of 1984, which amended the 1916 Act, eased government economic regulation of ocean transportation. ${ }^{14}$ The Act permitted service contracts between shippers and carriers/conferences and authorized door-todoor (intermodal) rather than just port-to-port rates. ${ }^{15}$

The door-to-door rate provision of the Shipping Act of 1984 enabled container shipping lines to develop more cost-efficient ocean transportation networks - cargo could now move by an intermodal (that is, door-to-door) rate, leaving the choice of port-of-call to the shipping line, which incurred cost savings in using larger container ships (from economies of ship size) to call at load-center ports, where containers were accumulated. Since the transport of cargo to and from regions via the nearest port could no longer be guaranteed, U.S. container ports found themselves competing not only with neighboring ports, but also against ports hundreds of miles away. For cargo moving under a port-to-port rate, the shipper (or authorized party) is responsible for hiring inland carriers to transport cargo to and from ports. Under a door-to-door rate, the shipping line has this responsibility. The door-to-door rate provision also enabled shipping lines to obtain, given their large volumes of container cargo, lower rates from inland carriers for the inland transportation of containers than could have been obtained by individual shippers.

The railroad service contract provision of the Staggers Act of 1980 and the greater availability of truck service contracts following passage of $1980 \mathrm{MCA}$, in conjunction with the door-to-door rate provision of the 1984 Act, enabled shipping lines to obtain even lower rail and truck rates (that is, in addition to those from volume discounts). The rail service contract provision allows railroads to enter into contracts with shipping lines, thus providing the opportunity for the latter to negotiate lower (that is, contract) rail rates as well as rail service improvements.

In 1984, the U.S. flag container shipping line, APL, began offering landbridge service ${ }^{16}$ - that is, rather than all-water service across the Pacific, through the Panama Canal, to the East Coast,

\footnotetext{
${ }^{13}$ Liner conferences are shipping line cartels that provide scheduled vessel service over specific trade routes and collectively discuss and set rates, usually only port-to-port rates. Liner conferences have immunity from anti-trust legislation in most OECD (Organization for Economic Cooperation and Development) countries.

${ }^{14}$ Discussion of the Shipping Act of 1984 is found in Frankel (1986), Chadwin, Pope and Talley (1990), and Cassavant and Wilson (1991).

${ }^{15}$ The "independent rate action" and the "intermodal rate-making" provisions of the Shipping Act of 1984 reduced the ability of U.S. liner conferences to set rates. The Ocean Shipping Reform Act of 1998 (which amended the 1984 Act and took effect May 1, 1999) reduced this ability even further and contributed to the further decline of conferences. Its "confidential contract" provision allows, for the first time, confidential one-on-one contracts by shipping lines, but not conferences, with their customers. Other major provisions of the 1998 Act include: a) shippers remain subject to standard U.S. antitrust law and ocean carriers are still subject to Federal Maritime Commission (FMC) regulation; b) individual carrier tariff-filing requirements with the FMC have been eliminated, but carriers are required to publish rates via the Internet or other media; c) contracts must be filed with the FMC for agency oversight; and d) ocean carriers engaged in confidential arrangements with big shippers must disclose contractual information regarding specific dock and port movements to longshore unions. Between May 1, 1999 and May 31, 2000, 46,035 new service contracts and 95,627 contract amendments were filed with the FMC. During 1999 the number of active conference agreements on file at the FMC dropped from 33 to 22.

${ }^{16}$ Some authors have distinguished among landbridging, minibridging, and microbridging: landbridging referring to cargo movement that crosses a body of land between two ocean legs; minibridging referring to cargo movement that crosses one ocean by ship and then crosses a body of land but ends at a port on another ocean; and microbridging
} 
its ships began calling at ports along the U.S. West Coast, where containers were unloaded and put on rail cars for the trip east. APL contracted with railroads to operate double-stack trains over their rail lines. Double-stack trains consist of platform rail cars capable of moving containers stacked two high. Their appeal is their cost advantage over conventional COFC (container-on-flat car) trains: for slightly more locomotive power, the same labor and slightly more fuel, 200 containers can be transported on a double-stack train as opposed to 100 containers on a COFC train. By the late 1980s the majority of the container cargo from Asia bound for the U.S. East Coast did not arrive by ship, but rather was discharged on the West Coast, and hauled by rail across the continent, thereby placing West Coast ports in competition with East Coast ports. Today, shipping lines contract with railroads to transport containers by double stack trains to and from ports on the West and East Coasts.

Lower ocean and inland transportation rates for ocean container cargo in the shipping deregulation period stimulated significant growth in containerized trade to and from the U.S. However, unlike U.S. container ports and port labor, the U.S. container shipping line (carrier) industry has benefited relatively little from the recent growth in containerized trade, since less than $5 \%$ of the ships involved in this trade are U.S. flagged (or over $95 \%$ are foreign flagged). Dockworker activity per se was not a target of shipping deregulation. Nevertheless, it is possible to link changes to shipping industry conditions with the demand for dockworker services.

\section{Dockworkers}

As early as the 1920s dockworkers were in excess supply at U.S. ports; both union and nonunion dockworkers competed for daily work assignments. ${ }^{17}$ In 1937 West Coast union dockworkers broke away from the International Longshoremen's Association (ILA) union to become the International Longshore and Warehouse Union (ILWU). In the 1940s and 1950s dockworker employers sought to introduce labor-saving devices, for example, lift trucks, but labor resisted with strikes and the threat of strikes. In the 1970s employers introduced containerization, the foremost port labor-saving technology.

Containerization radically altered cargo handling tasks, as capital was substituted for labor. ${ }^{18}$ Whereas a gang of 20 dockworkers could load 20 tons of cargo per hour on a break-bulk (general cargo on pallets) ship, one port crane and perhaps half as many men could load 400 to 500 tons of general cargo (in containers) per hour on a container ship. The demand for dockworkers dramatically declined. In the Port of New York/New Jersey, 30,000 longshoremen were employed in 1970; by 1986 this number had declined to 7,400 dockworkers (Chadwin, Pope and Talley, 1990). ${ }^{19}$ However, dockworkers were reluctant to accept changes attributable to

referring to cargo movement that crosses one ocean by ship and then proceeds by rail to an inland location (Chadwin, Pope and Talley, 1990). For this paper, landbridging is an all encompassing term, capturing all three of these possibilities.

${ }^{17}$ Dockworkers are workers involved in the movement of cargo within a port or marine terminal.

${ }^{18}$ For further discussion of ocean container transportation and its impacts, see Talley (2000).

${ }^{19}$ In the United Kingdom, dock jobs fell from 80,000 in 1967 to 11,400 in 1986 (Chadwin, Pope and Talley, 1990).

Even in recent years, significant losses have occurred. In the United Kingdom, port employment declined by $44 \%$ 
containerization and negotiated "work preservation" schemes that contributed to the rising surplus of registered dockworkers.

As for railroad workers and truck drivers, the productivity of dockworkers has also increased in the related-carrier (that is, shipping) deregulation period, primarily as a result of improvements in port communication and information technologies, infrastructures and cranes. However, unlike railroad workers and truck drivers, the bargaining power of dockworkers has increased in the deregulation period. There are two key factors contributing to this improvement: (1) the increases in the demand for dockworkers ${ }^{20}$ produced by the overall expansion of demand for shipping, in particular, for container cargo, and (2) the reluctance of dockworker employers to chance a strike (given the rising costs from disruptions in the utilization of expensive port infrastructures and container ships and the increase in port competition).

As stated previously, the door-to-door rate provision of the Shipping Act of 1984 enabled container shipping lines to develop more cost-efficient ocean transportation networks in U.S. trades and obtain lower rates (from volume discounts) for the inland transportation of ocean container cargo. In addition, the service contract provision of the Staggers Act of 1980 and the greater availability of truck service contracts following passage of the $1980 \mathrm{MCA}$, in conjunction with the door-to-door rate provision of the 1984 Act, enabled shipping lines to obtain even lower rail and truck rates. Shipping lines also contracted with railroads to transport containers, to and from ports on the West and East Coasts, on more cost-efficient double stack trains. Lower ocean and inland transport rates (from lower transportation costs) and lower shipper inventory and other logistics costs from improvements in ocean and inland transportation services (from service contracts) in the deregulation period stimulated the growth in container cargo in U.S. trades and the demand for dockworkers. ${ }^{21}$ The growth in cargo was also stimulated by globalization and reduction in trade barriers.

The response of U.S. ports and shipping lines to the growth in container cargo in U.S. trades was to invest billions of dollars in the expansion and improvement of container marine terminals and in larger container ships, thereby increasing the costs from disruptions in the utilization of port infrastructures and container ships. As a consequence, dockworker (port) employers are more reluctant to chance a strike - agreeing to settle labor contract extensions much earlier (prior to contract expiration) than in the past and to higher dockworker wage demands than would have occurred under more lengthy negotiations.

between 1989 and 1992. In France work rule reforms, introduced in 1992, led to employment declines of up to 66\% in six major ports. In Australia, waterfront reforms introduced in 1989 led to a 42\% two-year reduction in stevedore labor.

${ }^{20}$ Since the passage of the Shipping Act of 1984, the once chronic surplus in dockworkers has declined substantially, even resulting in a shortage of dockworkers at some ports. In July 2002 the Waterfront Commission of New York Harbor, the organization that licenses dockworkers and controls the labor supply in the Port of New York and New Jersey, agreed to allow up to 753 new longshoremen to work in the port. This was the first large scale opening of the longshore rolls in New York harbor since May 2000 when the commission allowed 481 new entrants into the industry (Dupin, 2002).

${ }^{21}$ The deregulation of the railroad and trucking industries, by lowering the costs of transporting cargo to and from ports, has benefited the shipping line industry, a third industry whose services are largely complements to those of the former industries, and by extension a labor market associated with it. 
Dockworker employers are also more reluctant to chance a strike in fear of cargo shifting to a port competitor. The door-to-door rate provision of the 1984 Act reduced the natural hinterlands of U.S. container ports, thereby increasing port competition, since cargo to and from regions via the nearest port could no longer be guaranteed.

Between World War II and the mid-1970s the ILA struck at the end of almost every master contract. $^{22}$ ILA employers, however, have become increasingly reluctant to risk dockworker strikes. "They (employers) are willing to pay higher wages - an ever-decreasing percentage of total costs (for container ports) - in exchange for being able to keep their ships, cranes, chassis, and other equipment running" (Armbruster, 2000, p. 17). ${ }^{23}$ In June 2000 ILA members approved (by more than 3-to-1) a three-year master contract extension, the third time in recent years that a contract extension had been approved without full-scale negotiations between the ILA and its employers. Further, the contract was approved more than a year before the old master contract was to expire. The current contract will expire September 30, 2004; master-contract negotiations between the union and management began in October 2003.

The ILWU has also signed favorable contracts in recent years. "Maritime industry sources agree the ILWU contract that will be in effect until July 1, 1999 was negotiated from a position of almost absolute power by the union" (Mongelluzzo, 1996, p. 1B). The contract gave the ILWU a 9\% wage increase in the first year and expanded jurisdiction into harbor trucking with no give-backs by the union. The 1999 ILWU contract expanded the union's jurisdiction, whereby employers agreed to train longshoremen for container maintenance and repair. The ability of the ILWU to resist the implementation of information technology is further evidence of its increased bargaining power. In December 1999 the ILWU at the Ports of Long Beach and Los Angeles rejected the implementation of a computerized job-dispatching system designed for getting dockworkers to start work on time. The ILWU chose to retain the cumbersome manual system used for decades (dating back to the ILWU's founding) of posting job assignments on a dispatch-hall chalkboard and manually writing work order tickets at the start of each shift. The ILWU views the computerized dispatch system as "an attempt by employers to eventually regain control of the dispatch hall" (Mongelluzzo, 1999, p. 1).

The ILWU contract which was to expire on July 1, 2002 was extended on a day-to-day basis by the ILWU until September 1, 2002, followed by ILWU work slowdowns. ${ }^{24}$ By September 30, 2002, productivity at West Coast ports had dropped 50 percent. The Pacific Maritime Association (PMA) which represents West Coast ports in bargaining with the ILWU responded with a lock-out of the union. The 10-day lockout ended when a federal judge, at the request of

\footnotetext{
${ }^{22}$ The ILA negotiates coast-wide master and local contracts with individual ports, stevedores and marine-terminal operators which directly employ them but also compete with each other for cargo. Alternatively, the ILWU negotiates with one coast-wide employer association, the Pacific Maritime Association (PMA).

${ }^{23}$ The substitution of capital for labor under containerization increased (reduced) capital's (labor's) share of port costs. Bulk and break-bulk cargoes are more labor intensive than container cargo; their labor costs represent a higher percentage of port costs than those of container ports. Thus, U.S. Gulf Coast ports which specialize in bulk and break-bulk cargoes have had an incentive to switch to non-ILA labor.

${ }^{24}$ In its 1996 and 1999 contract negotiations, the ILWU had successfully leveraged its slowdowns to win concessions from employers.
} 
President Bush, invoked the Taft-Hartley Act, imposing an 80-day cooling-off period during which negotiations between the PMA and the ILWU would resume under federal mediation by the Federal Mediation and Conciliation Service. During the lockout, 200 vessels lay in anchorage at West Coast ports, resulting in a cargo backlog that would require six weeks to clear and in millions of dollars in losses to shipping lines and U.S. and Asian shippers.

On November 23, 2002, the PMA and the ILWU agreed to a tentative six-year contract that was subsequently ratified by ILWU members. The contract provides a framework for implementing new technology for increasing productivity at West Coast ports. In return, the ILWU will receive an increase of \$3 per hour in its hourly base wage of \$27.68 over the six-year contract, a 58 percent increase in pension benefits, and job protection guarantees to ensure that no currently registered worker will lose a job as a result of technology. The mediated contract was "the most lucrative in the union's 70-year history" (Tirschwell, 2003, p. 6) and "more favorable to employers than they could have achieved on their own" (Mongelluzzo, 2003, p. 26).

The disruption of the 10-day lockout to the U.S. economy and role of the ILWU in this disruption have led to a negative national reputation for the union. ${ }^{25}$ The ILWU is now fearful that the federal government will act to reduce its bargaining power. ${ }^{26}$ The speculation is that Congress will remove labor relations at U.S. ports from the National Labor Relations Act and place them under the 1926 Railway Labor Act - which eliminates the ability of a union to use the threat of a strike to gain the upper hand in contract negotiations. The latter Act was created when railroads had a monopoly on long-distance transportation, "a situation some would say bears a striking resemblance to the ILWU's monopoly on West Coast port labor" (Tirschwell, 2002, p. 6). Also, there is the threat that more cargo will be diverted from West Coast ports, because of the labor unrest at these ports, to East Coast ports via the Panama Canal.

The ILWU is also concerned about possible negative spillover effects from the port services directive proposed by the European Union (EU). The directive would ease regulatory constraints on port operators to create more competition in EU ports as well as give ship owners the option of handling cargo on their own vessels (thereby creating "ports of convenience"). Proponents shipowners, shippers and a number of European port operators - see the directive as means for improving port efficiency and decreasing shipping costs. Union dockworkers who are opponents see the directive resulting in job losses, not only from the use of seafarer labor, but also from the use of unregistered casual dock labor (made easier by the directive) to handle port cargo.

The International Transport Workers' Federation (ITF), to which a number of transportrelated unions including the ILWU are affiliated, organized a campaign of strikes and work stoppages by EU dockworker unions against passage of the directive. In January 2003 dockworkers strikes resulted in the blockage to entry to all ports in Finland and Belgium, the partial shutdown of the German ports of Hamburg and Bremerhaven and worker slowdowns at

25 "The West Coast docks are crucial to the commerce of the nation, handling 52 percent of all waterborne imports to the United States - equal to about 7 percent of the nation's gross domestic product" (Swoboda, 2002, p. E01).

${ }^{26}$ Some evidence of this fear may be found in a recent reaction by the ILWU to a change in hiring at the ports of Los Angeles and Long Beach. On September 8, 2003 the ports of Los Angeles and Long Beach ordered one fewer dockworker to serve as ground workers for each crane. Two days of ILWU slowdowns followed, but were abruptly ended by an arbitration ruling against the union; no subsequent ILWU slowdowns in response to this change in hiring have occurred. 
the Port of Rotterdam. During the first six months of 2003, 20,000 dockworkers were involved in directive strikes. In September 2003, 7000 dockworkers from Netherlands, Belgium, France, Spain and Germany were involved in 24-hour strikes at EU ports.

In November 2003, the opponents of the directive were to triumph: The European Parliament voted 229 to 209 against passage of the directive (Barnard, 2003). However, speculation remains that new port reform proposals (without the "self-handling" clause) will be submitted to the European Parliament and port users will take legal action to reduce their port cargo-handling costs. In any event, the directive, although not adopted, will likely be the precedent upon which governments will adopt legislation to reduce port costs, including dockworker costs.

\section{$4 \quad$ Data and wage model}

U. S. Current Population Survey (CPS) data for the years 1973-97, excluding 1982, are used to investigate the wage differentials (that is, the relative wages) of U. S. truck drivers and rail engineers (of the for-hire truck and railroad carrier industries) versus U.S. port dockworkers. For the 1973-81 period, May CPS tapes are used, while 12-month CPS tapes are used for the 198397 period. ${ }^{27}$ Union-status information on 12-month CPS tapes is not available prior to 1983. Since the survey did not collect union status information in 1982, this year is omitted. The sample includes individual workers who worked 30 or more hours per week. For this study the CPS data have two shortcomings: First, the data contain labor earnings, but not benefits; ideally, one would prefer to analyze workers' total compensation packages of earnings and benefits. Second, the CPS survey typically does not collect information on respondents' employers; consequently, the investigation is unable to control for firm characteristics.

Hourly wage differentials of truck drivers and railroad engineers versus port dockworkers for a given regulation (or deregulation) period are investigated by estimating the wage equation

(1) $\operatorname{lnHRWAGE} \mathrm{ij}_{\mathrm{j}}=\alpha_{1} \mathrm{OCCUP}_{\mathrm{ij}}+\alpha_{2} \mathrm{UNEM}_{\mathrm{ij}}+\Sigma \alpha_{\mathrm{k}} X_{\mathrm{ijk}}+\varepsilon_{\mathrm{ij}}$,

where lnHRWAGE $\mathrm{ij}_{\mathrm{ij}}$ is the natural log of the hourly wage in 1982-84 dollars of the ith worker in the jth year, ${ }^{28}$ OCCUP is a binary variable equal to 1 for an occupation, other than a dockworker, and 0 if a dockworker; and UNEM is the annual U.S. national civilian unemployment rate and is included to control for possible cyclical changes in the economy. ${ }^{29} \mathrm{X}$ is a vector of control variables which includes a constant term as well as the variables: years of schooling completed (SCHOOL); years of work experience (EXPER), approximated as age - SCHOOL - 5; years of experience squared/100 (EXPERSQ); and binary variables equal to 1 if the driver is white

\footnotetext{
${ }^{27}$ The May CPS tapes were obtained from the Inter-University Consortium for Political and Social Research (ICPSR). The 12-month CPS tapes were obtained from the Data Services Group at the U.S. Bureau of Labor Statistics.

28 The Consumer Price Index (CPI) was used to deflate hourly and weekly wages.

${ }^{29}$ UNEM data are the national civilian unemployment rates for the observation years and are taken from the U.S. Bureau of Labor Statistics, Geographic Profile of Employment and Unemployment (various years).
} 
(WHITE), married (MARRIED), or working in the Northeast (NORTHEAST), South (SOUTH) or West (WEST), as opposed to working in the North Central region of the country. The parameter $\alpha_{1}$ measures the log hourly wage differential between an occupation, other than dockworker, and a dockworker.

Weekly wage differentials are investigated by estimating the wage equation

(2) $\operatorname{lnWKWAGE} \mathrm{ij}_{\mathrm{ij}}=\beta_{1}$ OCCUP $_{\mathrm{ij}}+\beta_{2} \operatorname{lnHOURS}_{\mathrm{ij}}+\beta_{3} \mathrm{UNEM}_{\mathrm{ij}}+\Sigma \beta_{\mathrm{k}} \mathrm{X}_{\mathrm{ijk}}+\varepsilon_{\mathrm{ij}}$,

where $\ln W K W A G E_{\mathrm{ij}}$ is the natural log of the weekly wage in 1982-84 dollars of the ith worker in the jth year; lnHOURS is the natural log of the weekly hours worked of the ith worker in the jth year; and the remaining explanatory variables are the same as those in equation (1). Since weekly wage and hours worked are expected to be positively related, lnHOURS is included as an explanatory variable to avoid omitted-variable estimation bias. The parameter $\beta_{1}$ measures the log weekly wage differential between workers of an occupation, other than dockworker, and a dockworker. The robustness of wage differential conclusions is checked by comparing hourly and weekly wage differential estimates.

The regulation (deregulation) period is a period of time for which industries for both the occupation, other than dockworker, and the dockworker are under economic regulation (deregulation). Specifically, the 1973-78 time period is the regulation period for the truck driver and dockworker pairing; 1973-79 is the regulation period for the rail engineer and dockworker pairing. The 1984-97 period is the deregulation period for both pairings.

As in the Rose (1987) and Hirsch (1988) studies, 1979 is selected as the first year of the truck deregulation period, reflecting administrative deregulation prior to passage of the 1980 MCA. Although the 4-R Act of 1976 was the initial railroad deregulation act, it "was largely emasculated by the ICC which was inclined to oppose deregulation or move only slowly towards deregulation" (Grimm and Windle, 1998, p. 18). Talley and Schwarz-Miller (1998) found no significant changes in the real weekly wages of union railroad engineers during the 1976-79 period but did found significant changes following passage of the Staggers Act. Hence, 1980 is selected as the first year of the railroad deregulation period. The first year of the shipping deregulation period is 1984, the year that the Shipping Act was passed.

In Table 1, mean real hourly wages, real weekly wages, and weekly hours worked for union truck drivers, rail engineers, and dockworkers for regulation and deregulation periods are presented. The table reveals that the mean real hourly and weekly wages of union truck drivers and railroad engineers declined during the deregulation periods, but those of dockworkers increased. The mean real weekly wages of truck drivers and railroad engineers fell from $\$ 579$ and $\$ 656$ during regulation to $\$ 503$ and $\$ 611$ during deregulation, respectively, whereas dockworkers experienced an increase from $\$ 478$ to $\$ 589$. The mean weekly hours worked were similar for both time periods for each occupation.

\begin{tabular}{|c|c|c|c|c|c|c|c|}
\hline & \multicolumn{3}{|c|}{ Regulation $^{\mathrm{a}}$} & \multicolumn{4}{|c|}{ Deregulation $^{b}$} \\
\hline Occupation & $\begin{array}{l}\text { Hourly } \\
\text { Wage }\end{array}$ & $\begin{array}{l}\text { Weekly } \\
\text { Wage }\end{array}$ & $\begin{array}{l}\text { Weekly } \\
\text { Hours }\end{array}$ & $\mathrm{N}$ & $\begin{array}{l}\text { Hourly } \\
\text { Wage }\end{array}$ & $\begin{array}{l}\text { Weekly } \\
\text { Wage }\end{array}$ & $\begin{array}{l}\text { Weekly } \\
\text { Hours }\end{array}$ \\
\hline
\end{tabular}




\begin{tabular}{|l|l|l|l|l|l|l|l|l|}
\hline Truck Driver & 919 & 12.07 & 579.21 & 48.0 & 3911 & 10.66 & 502.86 & 47.5 \\
\hline Rail Engineer & 169 & 14.01 & 656.43 & 47.8 & 802 & 13.03 & 610.50 & 47.8 \\
\hline Dockworker & 144 & 11.57 & 477.68 & 41.5 & 309 & 13.97 & 588.58 & 42.1 \\
\hline
\end{tabular}

Table 1: Union mean real wages and hours worked for truck, railroad and dockworker occupations

Notes: ${ }^{\text {a}}$ Years 1973-78 for truck drivers; years 1973-79 for rail engineers; and years 1973-83, excluding 1982, for dockworkers. ${ }^{\text {b}}$ Years 1984-97.

While the sample sizes for non-union truck drivers for the two time periods are relatively large, those for non-union rail engineers and dockworkers are relatively small, especially those for dockworkers (with 24 and 27 observations, respectively, for the regulation and deregulation time periods). Consequently, estimates of the two equations for non-union workers are not presented, nor are their mean statistics.

\section{$5 \quad$ Estimation results}

Estimates of wage equations (1) and (2) for union truck drivers and rail engineers versus dockworkers, for regulation and deregulation time periods, are presented in the Appendix. Also, wage equation estimates for a control group of non-transport operatives versus dockworkers are presented. The non-transport operatives are comparable in skill requirements to truck drivers, rail engineers and dockworkers. ${ }^{30}$ Since the wages of non-transport operatives are expected to reflect labor market forces in the economy at large (and are not directly affected by transportation regulation and deregulation), the wage equation estimates for non-transport operatives versus dockworkers represent an indirect control for these forces. Possible estimation bias from omission of relevant explanatory variables is addressed by including annual time binary variables in the estimations. Since wage differentials are the primary interest of this study, the OCCUP coefficient estimates from the wage equations in the Appendix are also presented in Table 2.

In Table 2, the regulation OCCUP coefficient estimates for union truck drivers versus dockworkers are insignificant and negative, while those for union rail engineers versus dockworkers are also insignificant but positive. By contrast, the deregulation OCCUP coefficient estimates for truck drivers versus dockworkers are negative and statistically significant, in fact highly significant, and robust. The hourly wage coefficient estimate for rail engineers versus dockworkers is negative and significant at the $2 \%$ level, while the weekly wage coefficient is

\footnotetext{
${ }^{30}$ The CPS sample of non-transport operatives includes: lathe and turning machine operators (704), welders and cutters (783), and production inspectors and examiners (796). The numbers in parentheses are the occupational codes assigned by the U.S. Department of Commerce to these occupations. Non-transport operatives were also used as a control group by Hirsch (1988) in his study of the impact of the deregulation on truck driver wages.
} 
negative but insignificant. The negative hourly wage OCCUP coefficients for the truck driver and rail engineer pairings for the deregulation period indicate that union hourly wages were $22.7 \%$ and $6.9 \%$ lower for these occupations than for dockworkers, respectively; for union truck driver weekly wages, the negative wage gap is $20.4 \% .^{31}$

\begin{tabular}{|c|c|c|c|c|}
\hline & \multicolumn{2}{|c|}{ Regulation $^{\mathrm{b}}$} & \multicolumn{2}{|c|}{ Deregulation $^{\mathrm{c}}$} \\
\hline Occupation & $\begin{array}{l}\text { Hourly } \\
\text { Wage }\end{array}$ & $\begin{array}{l}\text { Weekly } \\
\text { Wage }\end{array}$ & $\begin{array}{l}\text { Hourly } \\
\text { Wage }\end{array}$ & $\begin{array}{l}\text { Weekly } \\
\text { Wage }\end{array}$ \\
\hline Truck Driver & $\begin{array}{l}-.0505 \\
(-1.20) \\
\end{array}$ & $\begin{array}{l}-.0143 \\
(-0.35) \\
\end{array}$ & $\begin{array}{l}-.2570 \\
(-10.54) \\
\end{array}$ & $\begin{array}{l}-.2285 \\
(-9.35) \\
\end{array}$ \\
\hline Rail Engineer & $\begin{array}{l}.0605 \\
(0.97) \\
\end{array}$ & $\begin{array}{l}.0803 \\
(1.28) \\
\end{array}$ & $\begin{array}{l}-.0717 \\
(-2.35)\end{array}$ & $\begin{array}{l}-.0308 \\
(-0.99)\end{array}$ \\
\hline $\begin{array}{l}\text { Non-transport } \\
\text { Operative }\end{array}$ & $\begin{array}{l}-.1795 \\
(-5.69) \\
\end{array}$ & $\begin{array}{l}-.1779 \\
(-5.66) \\
\end{array}$ & $\begin{array}{l}-.3752 \\
(-13.67) \\
\end{array}$ & $\begin{array}{l}-.3852 \\
(-14.12) \\
\end{array}$ \\
\hline
\end{tabular}

Table 2: Estimated union wage differential coefficients: alternative occupations versus dockworker $^{\mathrm{a}}$

Notes: ${ }^{a}$ t-statistics are in parentheses. ${ }^{b}$ Years 1973-78 for truck drivers; years 1973-79 for rail engineers; and years 1973-83, excluding 1982, for non-transport operatives. ${ }^{c}$ Years 1984-97.

A comparison of the wage differential coefficients found in Table 2 suggests that for the regulation period the union wages of truck drivers, rail engineers and dockworkers were comparable, but for the deregulation period the union wages of truck drivers and engineers declined relative to those of dockworkers, the former more so than the latter. That is to say, the union wage differentials among truck drivers, rail engineers and port dockworkers (workers of an inter-related industry to transportation carrier industries) have widen under transportation carrier deregulation - the union wages of dockworkers have increased relative to those of rail engineers and the union wages of rail engineers have increased relative to those of truck drivers - a result similar to that found among deregulated transportation carrier industries themselves. ${ }^{32}$

Are our findings with respect to the dockworker a reflection of carrier regulation and deregulation or merely a reflection of trends in the general economy? This question is addressed by pairing non-transport operatives and dockworkers in the estimations of equations (1) and (2). In Table 2 the OCCUP coefficient estimates for non-transport operatives versus dockworkers are

\footnotetext{
${ }^{31}$ The percentage differentials were derived from the equation $\left(\mathrm{e}^{\forall}-1\right) 100$, where $\forall$ is the OCCUP coefficient.

${ }^{32}$ Forces that affect the wage differentials among dockworkers, railroad engineers and truck drivers are generally the same as those that affect the wage differentials among the occupations of transportation carrier industries, for example, labor-saving technologies, labor productivity, and industry competition, growth and financial health. Talley (2001) found that such forces likely contributed to the "fanning out" of the wages of U.S. railroad engineers, truck drivers and motor bus drivers during deregulation. The same forces which produced the further trailing behind of motor-bus driver wages (at the bottom), for example, industry weakness, also produced the improvement in dockworker earnings (at the top), for example, industry growth. For further discussion of these forces for the above occupations, see Talley (2001) and Schwarz-Miller and Talley (2002).
} 
negative and highly significant for both time periods. The negative coefficients for the shipping regulation period indicate that the union hourly and weekly wages of non-transport operatives were $16.4 \%$ and $16.3 \%$ less than those of dockworkers, whereas for the shipping deregulation period they were $31.3 \%$ and $32.0 \%$ less. Note that the union wage gaps for non-transport operatives versus dockworkers were significant in the regulation period, unlike those for the truck driver and rail engineer pairings which were insignificant. Also, the negative wage gaps for non-transport operatives versus dockworkers in the deregulation period are greater than those for the truck driver and rail engineer pairings. These results thus suggest that the absolute and relative improvement of dockworker wages is not a reflection of positive labor market forces in the economy at large. ${ }^{33}$

Why have the union wages of truck drivers and rail engineers declined relative to those of dockworkers in the deregulation period? The primary reason appears to be the change in the relative bargaining power among the occupations in the deregulation period. For both truck carriers and railroads, there has been a shift in the balance of power in wage negotiations from unions to management in this period. For truck carriers, this shift occurred subsequent to deregulation as evident by the substantial decline in truck carrier participation in industry-wide labor contracts. For the railroad industry, this shift was not apparent until 1985 (Talley and Schwarz-Miller, 1998). Conversely, for dockworkers, there has been a shift in the balance of power in wage negotiations from management to unions in the deregulation period. Port dockworker employers are settling labor contract extensions much earlier (prior to contract expiration) than in the past and agreeing to higher dockworker wage demands than would have occurred under more lengthy negotiations. ${ }^{34}$

\section{Conclusion}

This paper has investigated occupational wage differentials among U.S. intermodal transportation carrier (railroad and truck) industries and an inter-related (the port) industry under carrier regulation and deregulation. Specifically, wage differentials were estimated for rail engineers and truck drivers versus port dockworkers under railroad, truck and shipping carrier regulation and deregulation. The estimation results suggest that the union wages of rail engineers, truck drivers and dockworkers were comparable in the regulation period; in the deregulation period the union wages of rail engineers and truck drivers declined relative to those of dockworkers, the latter more so than the former. For the deregulation period, the estimates

\footnotetext{
${ }^{33}$ If the rate elasticity of demand for the end product is greater for railroads and truck carriers than for shipping lines - due to the enhanced intermodal competition among the land carriers under deregulation - a growing wage differential in favor of dockworkers relative to railroad engineers and truck drivers would be expected.

${ }^{34}$ The increase in the relative bargaining power of dockworkers in the deregulation period may also reflect the labor saving effects of technological change occurring earlier for dockworkers (with containerization starting well before deregulation) than for railroad engineers and truck drivers and playing themselves out by the time of deregulation. Further, the increase in the relative bargaining power of dockworkers may be enhanced by the bargaining structure itself, that is, the bargaining negotiations may be between dockworkers and ports which are not the ultimate employers of dockworkers, excluding shipping lines which are the ultimate employers.
} 
indicate negative union hourly wage gaps of $6.9 \%$ and $22.7 \%$ for rail engineers and truck drivers, respectively, versus dockworkers. Thus, the wage gaps among the occupations have widen under carrier deregulation - the union wages of dockworkers have increased relative to those of rail engineers and the union wages of rail engineers have increased relative to those of truck drivers - a result similar to that found among deregulated transportation carrier industries themselves.

The primary reason for the widening in the wage gaps among the occupations in the deregulation period appears to be the change in the relative bargaining power among the occupations. For both truck carriers and railroads, there has been a shift in the balance of power in wage negotiations from unions to management. For dockworkers, the shift has been from management to unions. However, the bargaining power of U.S. dockworkers (especially that of the ILWU) may decline in the future. The threats to this power include: Congress removing labor relations at U.S. ports from the National Labor Relations Act and placing them under the 1926 Railway Labor Act, further diversion of container cargo from West to East Coast ports and negative spillover effects from the port services directive proposed (although not adopted) by the EU.

\section{$7 \quad$ References}

Armbruster, W. (2000) "Four More Years: ILA, Management Extend Master Contract into 2004," Joc Week, July 3-9: 17-18.

Association of American Railroads (2002) Railroad Facts. Association of American Railroads: Washington, D.C.

Babcock, M. W., and H. W. German (1991) "Public Policy Impacts on Transportation Employment," Southern Economic Journal, 58: 155-170.

Barnard, B. (2003) "No to Port Reform," Traffic World, 33-34.

Barnekov, C. C., and A. N. Kleit (1990) "The Efficiency Effects of Railroad Deregulation in the United States," International Journal of Transport Economics, 17: 21-36.

Belzer, M. H. (1995) “Collective Bargaining After Deregulation: Do the Teamsters Still Count?" Industrial and Labor Relations Review, 48: 636-655.

Boyer, K. D. (1987) "The Costs of Price Regulation: Lessons From Railroad Deregulation," Rand Journal of Economics, 18: 408-416.

Braeutigam, R. R. (1993) "Consequences of Regulatory Reform in the American Railroad Industry," Southern Economic Journal, 59: 468-480. 
Burton, M. L. (1993) "Railroad Deregulation, Carrier Behavior, and Shipper Response: A Disaggregated Analysis," Journal of Regulatory Economics, 5: 417-434.

Cassavant, K. L. and W. W. Wilson (1991) "Shipper Perspectives of the Shipping Act of 1984," Transportation Quarterly, 45: 109-120.

Chadwin, M. L., J. A. Pope and W. K. Talley (1990) Ocean Container Transportation: An Operational Perspective. Taylor \& Francis: New York.

Crum, M. R. (1989) "U.S. Transportation Management Developments Since Deregulation," International Journal of Transport Economics, 16: 263-295.

Dupin, C. (2002) "NY Waterfront Will Add More Than 700 Jobs,” JOC Online, July 23.

Frankel, E. G. (1986) "Economic and Commercial Implications of the U.S. Shipping Act of 1984," Logistics and Transportation Review, 22: 99-114.

Friedlaender, A. F., E. R. Berndt and G. McCullough (1992) "Governance Structure, Managerial Characteristics, and Firm Performance in the Deregulated Rail Industry." Brookings Papers in Economic Activity: Microeconomics 1992, 95-169. Brookings Institution: Washington, D. C.

Gil, A. (1986) "Some Labour Implications of Technological Change in Rail and Air Transport," International Labour Review, 125: 1-17.

Grimm, C. and R. J. Windle (1998) "Regulation and Deregulation in Surface Freight, Airlines and Telecommunications." in J. Peoples (ed), Regulatory Reform and Labor Markets, 15-49. Kluwer Academic Publishers: Boston, Massachusetts.

Hirsch, B. T. (1988) "Trucking Regulation, Unionization, and Labor Earnings: 1973-85," Journal of Human Resources, 23: 296-319.

Hirsch, B. T. and D. A. Macpherson (1998) "Earnings and Employment in Trucking: Deregulating a Naturally Competitive Industry." in J. Peoples (ed), Regulatory Reform and Labor Markets, 61-112. Kluwer Academic Publishers: Boston, Massachusetts.

Locklin, D. P. (1972) Economics of Transportation. Richard D. Irwin, Inc.: Homewood, Illinois.

MacDonald, J. M. (1989) "Railroad Deregulation, Innovation, and Competition: Effects of the Staggers Act on Grain Transportation," Journal of Law and Economics, 32: 63-96.

McFarland, H. (1987) "Did Railroad Deregulation lead to Monopoly Pricing? An Application of q," Journal of Business, 60: 385-400. 
McFarland, H. (1989) "The Effects of United States Railroad Deregulation on Shippers, Labor, and Capital," Journal of Regulatory Economics, 1: 259-270.

Monaco, K. A. and D. L. Belman (2004) "An Econometric Analysis of the Impact of Technology on the Work Lives of Truck Drivers." in J. Peoples and W. K. Talley (eds), Transportation Labor Issues and Regulatory Reform. JAI Press, Inc.: London, England, forthcoming.

Mongelluzzo, B. (1996) "Union Steered Contract Talks," Journal of Commerce, July 22, 1B \& 4B.

Mongelluzzo, B. (1998) "Work Stoppages Again Disrupt West Coast Ports," Journal of Commerce, July 15, 1A \& 14A.

Mongelluzzo, B. (1999) “Longshoremen Reject System to Automate Job Dispatching," Journal of Commerce, December 14, 1 and 4.

Mongelluzzo, B. (2003) 'PMA's New Face: Miniace's Team Will Be Assertive in Dealing With the ILWU," Journal of Commerce, October 13-19, 26-27.

Nebesky, W., B. S. McMullen and M. K. Lee (1995) "Testing for Market Power in the U.S. Motor Carrier Industry,” Review of Industrial Organization, 10, 559-576.

Peoples, J. (1998) "Deregulation and the Labor Market," Journal of Economic Perspectives, 12: 111-130.

Rich, S. M. (1986) "Changing Railway Technology in the United States and Its Impact Upon Railroad Employment Since 1945,” Transportation Journal, 25: 55-65.

Rose, N.L. (1987) "Labor Rent Sharing and Regulation: Evidence from the Trucking Industry," Journal of Political Economy, 95: 1146-78.

Schwarz-Miller, A.V. and W. K. Talley (2002) "Technology and Labor Relations: Railroads and Ports." in J. Bennett and D. Taras (eds), Technological Change and Employment Conditions in Traditionally Heavily Unionized Industries, a symposium issue of the Journal of Labor Research, 23: 513-533.

Swoboda, F. (2002) “On the Waterfront, It’s Union vs. Tech,” Washington Post, January 5: E01.

Talley, W. K. and A. V. Schwarz-Miller (1998) "Railroad Deregulation and Union Labor Earnings." in J. Peoples (ed), Regulatory Reform and Labor Markets, 125-153. Kluwer Academic Publishers: Boston, Massachusetts.

Talley, W. K. (2000) "Ocean Container Shipping: Impacts of a Technological Improvement," Journal of Economic Issues, 34: 933-948. 
Talley, W. K. (2001) "Wage Differentials of Transportation Industries: Deregulation Versus Regulation,” Economic Inquiry, 39: 406-429.

Talley, W. K. (2002) "Dockworker Earnings, Containerization and Shipping Deregulation," Journal of Transport Economics and Policy, 36: 447-467.

Tirschwell, P. (2002) “Looking Forward,” Journal of Commerce, October 21-27: 6.

Tirschwell, P. (2003) "Has the ILWU Been Tamed?" Journal of Commerce, October 29November 2: 6 .

U.S. Bureau of Labor Statistics. Geographic Profile of Employment and Unemployment. U.S. Government Printing Office: Washington, D. C.

Wilson, W. W. (1994) "Market-Specific Effects of Rail Deregulation," Journal of Industrial Economics, 42: 1-22.

\section{$8 \quad$ Appendix}

\begin{tabular}{|l|c|c|c|c|c|c|}
\hline & \multicolumn{2}{|c|}{ Truck Driver } & \multicolumn{2}{c|}{ Rail Engineer } & \multicolumn{2}{c|}{ Non-transport Operative } \\
\hline Variable & $\begin{array}{c}\text { Hourly } \\
\text { Wage }\end{array}$ & $\begin{array}{c}\text { Weekly } \\
\text { Wage }\end{array}$ & $\begin{array}{c}\text { Hourly } \\
\text { Wage }\end{array}$ & Weekly Wage & $\begin{array}{c}\text { Hourly } \\
\text { Wage }\end{array}$ & $\begin{array}{c}\text { Weekly } \\
\text { Wage }\end{array}$ \\
\hline SCHOOL & .0025 & .0030 & .0037 & .0044 & .0276 & .0071 \\
& $(0.48)$ & $(0.60)$ & $(0.37)$ & $(0.45)$ & $(12.64)$ & $(12.46)$ \\
\hline EXPER & .0139 & .0145 & .0010 & -.0008 & .0077 & .0078 \\
& $(3.98)$ & $(4.27)$ & $(0.15)$ & $(-0.12)$ & $(6.26)$ & $(6.38)$ \\
\hline
\end{tabular}


Review of Network Economics

\begin{tabular}{|l|c|c|c|c|c|c|}
\hline EXPERSQ & -.0282 & -.0296 & -.0046 & .0072 & -.0109 & -.0100 \\
& $(-4.13)$ & $(-4.48)$ & $(0.39)$ & $(0.61)$ & $(-4.29)$ & $(-4.33)$ \\
\hline WHITE & .1108 & .1391 & .1834 & .2055 & .0416 & .0374 \\
& $(3.23)$ & $(4.13)$ & $(2.27)$ & $(2.55)$ & $(3.42)$ & $(3.08)$ \\
\hline MARRIED & -.0651 & -.0561 & -.0778 & -.0627 & .1124 & .1100 \\
& $(-1.97)$ & $(-1.74)$ & $(-1.21)$ & $(-0.98)$ & $(10.87)$ & $(10.68)$ \\
\hline NORTH- & -.0874 & -.1076 & -.1740 & -.1770 & -.1115 & -.1094 \\
EAST & $(-3.58)$ & $(-4.49)$ & $(-2.62)$ & $(-2.69)$ & $(-10.47)$ & $(-10.31)$ \\
\hline SOUTH & -.0570 & -.0703 & -.0189 & -.0126 & -.0854 & -.0846 \\
& $(-2.26)$ & $(-2.86)$ & $(-0.32)$ & $(-0.22)$ & $(-7.64)$ & $(-7.60)$ \\
\hline WEST & .0028 & -.0112 & .0172 & .0025 & .0748 & .0754 \\
& $(0.10)$ & $(-0.43)$ & $(0.29)$ & $(0.04)$ & $(5.54)$ & $(5.62)$ \\
\hline InHOURS & & .6546 & & .7574 & & 1.3637 \\
& & $(13.62)$ & & $(6.99)$ & & $(25.61)$ \\
\hline OCCUP & -.0505 & -.0143 & .0605 & .0803 & -.1795 & -.1779 \\
& $(-1.20)$ & $(-0.35)$ & $(0.97)$ & $(1.28)$ & $(-5.69)$ & $(-5.66)$ \\
\hline UNEM & -.1035 & -.1065 & -.0767 & -.0454 & .1147 & .1147 \\
& $(-2.31)$ & $(-2.43)$ & $(-0.70)$ & $(-0.42)$ & $(5.01)$ & $(5.03)$ \\
\hline Constant & 2.8748 & 4.1447 & 2.7249 & 3.4550 & 1.2882 & .5080 \\
& $(11.40)$ & $(13.69)$ & $(4.53)$ & $(5.09)$ & $(10.08)$ & $(2.52)$ \\
\hline $\mathrm{R}^{2}$ & .061 & .268 & .174 & .369 & .123 & .208 \\
\hline \multirow{2}{*}{$\mathrm{R}^{2}$} & & & & & & \\
\hline$\#$ Observations & .047 & .256 & .116 & .322 & .120 & .205 \\
\hline
\end{tabular}

Table A1: Regulation union wage equation results: alternative occupations versus dockworker ${ }^{\mathrm{a}}$

Notes: ${ }^{a}$ t-statistics are in parentheses; years 1973-78 for truck drivers; years 1973-79 for rail engineers; and years 1973-83, excluding 1982, for non-transport operatives; estimated coefficients of annual time binary variables are not shown. 


\begin{tabular}{|c|c|c|c|c|c|c|}
\hline & \multicolumn{2}{|c|}{ Truck Driver } & \multicolumn{2}{|c|}{ Rail Engineer } & \multicolumn{2}{|c|}{ Non-transport Operative } \\
\hline Variable & $\begin{array}{c}\text { Hourly } \\
\text { Wage }\end{array}$ & Weekly Wage & $\begin{array}{l}\text { Hourly } \\
\text { Wage }\end{array}$ & $\begin{array}{l}\text { Weekly } \\
\text { Wage }\end{array}$ & $\begin{array}{c}\text { Hourly } \\
\text { Wage }\end{array}$ & $\begin{array}{c}\text { Weekly } \\
\text { Wage }\end{array}$ \\
\hline SCHOOL & $\begin{array}{l}.0256 \\
(6.97)\end{array}$ & $\begin{array}{l}.0263 \\
(7.21)\end{array}$ & $\begin{array}{l}.0120 \\
(1.72)\end{array}$ & $\begin{array}{l}.0137 \\
(1.98)\end{array}$ & $\begin{array}{c}.0409 \\
(16.41)\end{array}$ & $\begin{array}{c}.0379 \\
(15.99)\end{array}$ \\
\hline EXPER & $\begin{array}{l}.0098 \\
(4.04)\end{array}$ & $\begin{array}{l}.0112 \\
(4.66)\end{array}$ & $\begin{array}{l}.0207 \\
(4.28)\end{array}$ & $\begin{array}{l}.0209 \\
(4.38)\end{array}$ & $\begin{array}{c}.0233 \\
(14.53)\end{array}$ & $\begin{array}{c}.0232 \\
(14.57)\end{array}$ \\
\hline EXPERSQ & $\begin{array}{l}-.0129 \\
(-2.83)\end{array}$ & $\begin{array}{l}-.0149 \\
(-3.30)\end{array}$ & $\begin{array}{l}-.0335 \\
(-3.75)\end{array}$ & $\begin{array}{l}-.0343 \\
(-3.90)\end{array}$ & $\begin{array}{c}-.0374 \\
(-12.20)\end{array}$ & $\begin{array}{c}-.0369 \\
(-12.12)\end{array}$ \\
\hline WHITE & $\begin{array}{l}.0508 \\
(2.79)\end{array}$ & $\begin{array}{l}.0638 \\
(3.52)\end{array}$ & $\begin{array}{l}.0400 \\
(1.14)\end{array}$ & $\begin{array}{l}.0058 \\
(1.59)\end{array}$ & $\begin{array}{l}.0900 \\
(7.29)\end{array}$ & $\begin{array}{l}.0821 \\
(6.69)\end{array}$ \\
\hline MARRIED & $\begin{array}{l}.0576 \\
(3.34)\end{array}$ & $\begin{array}{l}.0616 \\
(3.60)\end{array}$ & $\begin{array}{l}.0008 \\
(0.02)\end{array}$ & $\begin{array}{l}.0095 \\
(0.29)\end{array}$ & $\begin{array}{l}.0512 \\
(4.56)\end{array}$ & $\begin{array}{l}.0506 \\
(4.55)\end{array}$ \\
\hline $\begin{array}{l}\text { NORTH- } \\
\text { EAST }\end{array}$ & $\begin{array}{l}.0196 \\
(1.27)\end{array}$ & $\begin{array}{l}.0069 \\
(0.45)\end{array}$ & $\begin{array}{l}-.0302 \\
(-0.81)\end{array}$ & $\begin{array}{l}-.0323 \\
(-0.87)\end{array}$ & $\begin{array}{l}-.0709 \\
(-6.43)\end{array}$ & $\begin{array}{l}-0634 \\
(-5.77)\end{array}$ \\
\hline SOUTH & $\begin{array}{l}-.0030 \\
(-0.18)\end{array}$ & $\begin{array}{l}-.0089 \\
(-0.54)\end{array}$ & $\begin{array}{l}-.0023 \\
(-0.07)\end{array}$ & $\begin{array}{l}-.0010 \\
(-0.03)\end{array}$ & $\begin{array}{l}-.0936 \\
(-8.00)\end{array}$ & $\begin{array}{l}-.0901 \\
(-7.75)\end{array}$ \\
\hline WEST & $\begin{array}{l}.1039 \\
(6.21)\end{array}$ & $\begin{array}{l}.0942 \\
(5.66)\end{array}$ & $\begin{array}{l}.1484 \\
(4.73)\end{array}$ & $\begin{array}{l}.1550 \\
(5.01)\end{array}$ & $\begin{array}{l}.0576 \\
(4.09)\end{array}$ & $\begin{array}{l}.0568 \\
(4.07)\end{array}$ \\
\hline $\operatorname{lnHOURS}$ & & $\begin{array}{c}.7457 \\
(24.13) \\
\end{array}$ & & $\begin{array}{c}.7058 \\
(12.96)\end{array}$ & & $\begin{array}{c}1.4638 \\
(31.51)\end{array}$ \\
\hline OCCUP & $\begin{array}{c}-.2570 \\
(-10.54) \\
\end{array}$ & $\begin{array}{l}-.2285 \\
(-9.35) \\
\end{array}$ & $\begin{array}{c}-0.0717 \\
(-2.35) \\
\end{array}$ & $\begin{array}{l}-.0308 \\
(-0.99) \\
\end{array}$ & $\begin{array}{c}-.3752 \\
(-13.67) \\
\end{array}$ & $\begin{array}{c}-3852 \\
(-14.12) \\
\end{array}$ \\
\hline UNEM & $\begin{array}{l}-.0053 \\
(-0.06)\end{array}$ & $\begin{array}{l}-.0360 \\
(-0.41)\end{array}$ & $\begin{array}{l}-6697 \\
(-3.99)\end{array}$ & $\begin{array}{l}-.6423 \\
(-3.88)\end{array}$ & $\begin{array}{l}.2662 \\
(1.95)\end{array}$ & $\begin{array}{l}.2737 \\
(2.02)\end{array}$ \\
\hline Constant & $\begin{array}{l}1.9698 \\
(3.00)\end{array}$ & $\begin{array}{l}3.1053 \\
(4.66)\end{array}$ & $\begin{array}{l}6.9471 \\
(5.54)\end{array}$ & $\begin{array}{l}7.7836 \\
(6.24)\end{array}$ & $\begin{array}{l}-.2803 \\
(-0.28)\end{array}$ & $\begin{array}{c}-2.0265 \\
(-1.98)\end{array}$ \\
\hline $\mathrm{R}^{2}$ & .068 & .179 & .140 & .264 & .137 & .243 \\
\hline & .063 & .174 & .121 & $\overline{\mathrm{R}^{2}}$ & .134 & .240 \\
\hline \# Observations & 4116 & 4116 & 1014 & 1014 & 6682 & 6682 \\
\hline
\end{tabular}

Table A2: Deregulation union wage equation results: alternative occupations versus dockworker ${ }^{\mathrm{a}}$

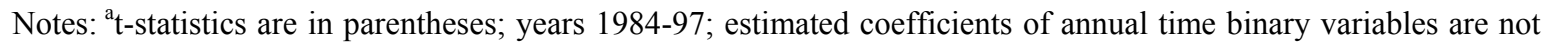
shown. 